\title{
PUBLIC AUTHORITIES ADMINISTERING THE FORMS OF NATURE CONSERVATION IN POLAND
}

\author{
Kamila Sobieraj*
}

\begin{abstract}
Specialized authorities in the field of environmental protection have existed since the beginning of the creation of the system of organization of environmental services and the amount of them has been steadily widening. This has been particularly evident in case of nature conservation law which is a part of environmental law. The fact of existence of authorities having specialized knowledge is particularly important in the context of new environmental tasks resulting from the implementation of European Union legal norms often using professional knowledge. The purpose of this article is to present the specialized authorities functioning in the field of nature conservation, the scope of taking advantage of their professional knowledge potential. The article also aims at taking of trial of assessment of adopted regulations accuracy concerning the division of tasks and competences of public authorities with regard to administration of forms of nature conservation, as well as presenting de lege ferenda comments aiming at nature conservation tasks performing more effectively.
\end{abstract}

Key words: nature conservation, public administration, national park, Natura 2000 sites

* PhD in Law - Assistant Professor at the Environmental Management Law Department, the Faculty of Law and Administration, The John Paul II Catholic University of Lublin. 


\section{INTRODUCTION}

According to the concept of law governing the legal protection of nature adopted by Polish legislator a form of nature conservation is one of the institutions that serves the execution of the purposes of nature conservation included in Article 2 item 2 of the Act of 16 April 2004 on Nature Conservation $^{1}$. It consists in the separation of the subject (area, object, species) which has some distinctive values, considering it as a protected by act of general application, covering it by a special legal regime, in which bans of behaviours threatening of this subject play a key role, and establishing of penal responsibilities for violation of these bans ${ }^{2}$.

Public administration to perform its duties in the field of environmental protection must have a highly specialized and diverse knowledge ${ }^{3}$. Decisions on the matters of environmental protection for their substantive correctness often require specialized knowledge covering not only a wide range of information in the field of law sciences and administration, but also the natural and engineering sciences, which general public authorities do not have. What's more, the growing dynamically number of legal norms of environmental protection, covering more and more extensive areas of issues, cause more and more internal specialization of this law, and in turn the necessity for further-reaching specialization of public administration and having particular specific knowledge by the authorities.

Polish legislator adopted that the tasks regarding nature conservation can be carried out by the general environmental authorities (listed in the content of Article 376 of the act of 27 April 2001 Environmental Protection Law ${ }^{4}$, including specialized environmental protection bodies: General

${ }^{1}$ Consolidated text Dziennik Ustaw [English: Journal of Laws] of 2015, item 1651 as amended.

${ }^{2}$ Wojciech Radecki, Ustawa o ochronie przyrody. Komentarz, Warsaw 2008, p. 65.

${ }^{3}$ Marek Górski, Wptyw nauk przyrodniczych i technicznych na treść, interpretację $i$ stosowanie norm prawa administracyjnego (na przyktadzie przepisów z zakresu prawnej ochrony środowiska, [in:] Stanisław Wrzosek, Michał Domagała, Jan Izdebski, Tadeusz Stanisławski (ed.), Wspótzależność dyscyplin badawczych w sferze administracji publicznej, Warsaw 2010, p. 4.

${ }^{4}$ Consolidated text: Dziennik Ustaw [English: Journal of Laws] of 2016, item 672 as amended. 
Director for Environmental Protection and regional directors for environmental protection), but also considered the need to isolate (additionally) specific bodies within the public administration regarding environmental protection, which are competent exclusively for nature conservation matters, for example director of the national park is currently considered by the legislature as a separate body of nature conservation ${ }^{5}$.

Nature conservation organization (has distinguished from the beginning and) is distinguished (in the context of activities of the specialized bodies) by few differences at the level of environmental law, which is a part of . A particular situation is a duty to act within nature conservation matters "with help" of nature conservator. Under the current Act on the Nature Conservation minister responsible for the environment protection performs its tasks "with help" of Chief Nature Conservator", and on the basis of the Act of 3 October 2008 on Access to Information regarding Environmental Protection and its Protection, Public Participation in Environmental Protection, and Impact Assessments on Environmental Protection $^{8}$, regional director for environmental protection performs its tasks "with help" of regional nature conservator. The act on Nature Conservation is one of only a few of other acts, which is a basis for taking activities by so many professional bodies?.

Polish legislator has rightly made an assumption, that it is essential to entrust mainly the specialized nature conservation authorises the following issues: appointing and elimination of areas characterized with stringent or mitigated protective rigours; determination of the applicable legal regime; the assessment of criteria justifying derogations introducing from the

${ }^{5}$ Wojciech Radecki, Organizacja ochrony środowiska...., p. 160; Aleksander Lipiński, Prawne podstawy ochrony środowiska, Warszawa 2007, p. 196.

${ }^{6}$ Janina Ciechanowicz-McLean, Prawo ochrony przyrody w systemie ochrony środowiska, Ochrona Środowiska. Prawo i Polityka [English: Environment Protection. Law and Policy] 2007, No. 1, p. 22.

${ }^{7}$ Article 92 item 1 of the Act on Nature Conservation.

${ }^{8}$ Consolidated text: Dziennik Ustaw [English: Journal of Laws] of 2016, item 353 as amended.

${ }^{9}$ Other example is the Act of 18 July 2001 - the Water Law, which regulates grounds for taking activities by bodies such as President of the National Water Management Board and directors of regional water management boards, Consolidated text: Dziennik Ustaw [English: Journal of Laws] of 2015, item 469 as amended. 
bans; preparation of conservation plans that are an essential management tool and performing other activities which require extensive professional knowledge. The premise of those activities performing is to recognize that the particular area or object is distinguished by specific values or virtues (or forever has lost them) and to identify conservation measures that will serve their conservation. Carrying out tasks regarding administration of forms of nature conservation must be based on a good knowledge of the diversity of flora and fauna on a local scale, it must be also taken into account the ecological role of the particular area, object or species on a scale of transnational (which a general public authorities does not have).

The purpose of this article is to present the specialized authorities functioning in the field of nature conservation, the scope of taking advantage of their professional knowledge potential. The article also aims at taking of trial of assessment of adopted regulations accuracy concerning the division of tasks and competences of public authorities with regard to administration of forms of nature conservation, as well as presenting de lege ferenda comments aiming at nature conservation tasks performing more effectively.

\section{NATURA 2000 SITES}

Poland accession to the European Union has result in creating of an extensive system of law regulations covering tasks for the public administration authorities regarding environment protection, which in turn led to changes in the authorities organizational sphere. European Union law does not generally interfere in the sphere of organization of the public administration authorities of the Member States. It is because of adopting the principle of the institutional autonomy, according to which the Member States' jurisdiction is to decide about the structure, powers and mode of operation of state bodies, including their appointing and liquidation ${ }^{10}$. Members

${ }^{10}$ Marta Woźniak, Rola samorządu terytorialnego w implementacji prawa wspólnotowego na przyktadzie prawa ochrony środowiska [in:] Jerzy Jendrośka, Magdalena Bar (ed.), Wspólnotowe prawo ochrony środowiska i jego implementacja w Polsce trzy lata po akcesji, Warsaw 2008, p. 101. 
States retain their organizational and procedural autonomies when they are involved with the exercising of European Union law. Every Member States is however obliged to organize their organizational authorities structures and divide the authorities duties in such a way that particular tasks deriving from European Union law are properly enforced. Therefore, increasing integration processes force partial changes within the national authorities organizational structure, which has to adopted to a new system of relations and actions aiming to achieve common goals.

The form of nature conservation, which the operation and administration has been treated in a special way by Polish legislator are Natura 2000 sites designated for securing of habitats and species identified as important on the European level. It is relatively new for Polish law regime, with no roots in the Polish legal and social cultures protective instrument introduced due to Poland accession to the European Union. Natura 2000 sites are also a form of nature conservation, which the operation and administration, has caused (especially for Polish public authorities) far-reaching problems. Among other incomplete, incorrect transposition of regulations regarding Birds ${ }^{11}$ and Habitats ${ }^{12}$ Directives into Polish national law contribute for this, but also surely difficulties with interpretation and application of these provisions often including professional knowledge. For example, regarding Natura 2000 sites, a general ban was introduced which does not allowed to take actions, that may individually or in combination with other measures, have any significant adverse effect on the objectives of Natura 2000 sites protection, in particular may deteriorate the natural habitats state and the state of habitats of plants species and animals species, as well as may have negative impact on species for protection of which Natura 2000 sites was designated, and may deteriorate the integrity of the Natura 2000 sites and its relations to other areas ${ }^{13}$. Proper interpretation and application of this ban and the premises that allow a derogation

${ }^{11}$ Directive 2009/147/EC of the European Parliament and of the Council of 30 November 2009 on the conservation of wild birds, Official Journal of the European Union No. L 20/7 dated 26.01.2010.

${ }^{12}$ Council Directive 92/43/EEC of 21 May 1992 on the conservation of natural habitats and of wild fauna and flora, Official Journal of the European Union No. L 206/7 dated 22.07.1992.

${ }^{13}$ Article 33 item 1 of the Act on Nature Conservation. 
from it (including the indication of overriding public interest) is an issue of utmost importance for an investor interested in obtaining a consent for the planned undertaking execution. However, it requires specialized knowledge and particular urgent analysis of opinions ${ }^{14}$ and guidelines of the Commission and the European Union Tribunal of Justice' cases in relation to the particular planned undertaking by the competent public authorities.

In the context of the new tasks arising from the European Union's commitments regarding environment protection, and as s result of changes introduced by two laws, which came into force on 15 November 2008, the office was created General Director for Environmental Protection and regional directors for environmental protection ${ }^{15}$. The need for the establishment of these bodies was argued in reasons of the draft of the Act of 3 October 2008 on the information about the environment access and its conservation, public participation in the environmental protection, and environmental impact assessment - the need to "provide high quality for public authorities to be properly specialized and profiled"16. Cumulating of environmental impact assessments regarding planned undertakings in the hands of one specialized body was to have effect on the acceleration of these procedures, reducing the number of required arrangements, ensuring the efficiency of absorption of European Union funds, ensuring a high level of formal and legal correctness of procedures conducting and material correctness of decisions making progress, and consequently reducing the risk of suing the way of procedures conducting before the national courts

${ }^{14}$ Widely in: S. Urban, Opinie Komisji Europejskiej w sprawie planów i przedsięwzięć negatywnie oddziatujacych na obszary Natura 2000; Problemy ocen środowiskowych [English: Problems with Environmantal Assessments] 2006, No. 1; idem Negatywne oddziatywanie planów i przedsięwzięć na sieć Natura 2000 a nadrzędny interes publiczny. Analiza pojęcia "powody o charakterze zasadniczym wynikajace z nadrzędnego interesu publicznego" [in:] Jerzy Jendrośka, Magdalena Bar, Wspólnotowe prawo ochrony środowiska i jego implementacja $w$ Polsce trzy lata po akcesji, Wrocław 2008, pp. 149-166; Zdzisław Brodecki (ed.), Ochrona przyrody przed Europejskim Trybunatem Sprawiedliwości. Komentarz, Marki 2010, p. 102.

${ }^{15}$ Act of 10 March 2008 amending the Nature Conservation Act and other acts, Dziennik Ustaw [English: Journal of Laws] of 2008 N. 201, item 1237.

${ }^{16}$ Sejm [chamber of Polish Parliament] Paper No. 768, reasons for the law draft, p. 27. 
and European Union Tribunal of Justice ${ }^{17}$. New public authorities have, amongst other, the management of nature conservation process improved, especially in regard to compliance with the European Union requirements deriving from so-called Birds Directive and Habitats Directive ${ }^{18}$.

With the entry into force of the Act of 3 October 2008 amending the Act of Nature Conservation, the activities related to Natura 2000 sites are generally performed by specialized bodies: both the central governmental administration (Ministry of the Environment, General Director for Environmental Protection), regional governmental administration (regional directors for environmental protection) and for example the director of the national park (if the Nature 2000 covers an area of national park). However, exceptions can be found, among others with regard to the environmental impact assessment of the planned undertakings on Nature 2000 sites. In case of undertakings other than those undertakings which are likely to have significant environmental effects, regional director for environmental protection is ultimately obliged to decide about the need of carrying out and carrying out so-called habitat assessment only if the authority issuing permit for the implementation of this particular undertaking, after considering requirements included in the content of Article 96 item 1 of Act of 3 October 2008 on the information about the environment access and its conservation, public participation in the environmental protection, and environmental impact assessment, finds that "the planned undertaking is likely to has the potential to have significant effect on Natura 2000"19. The authority initiating such an assessment would be often authority of general administration. Similarly, in the case of "undertaking that may potentially have a significant impact on the environment", it is often the decision of the general administration authority will settle about carrying out of (or not) the environmental impact assessment of the planned undertakings, including so-called habitat assessment. The authority conducting the proceeding resulting in the decision on environmental constraints issuing is

${ }^{17}$ Ibidem, p. 28.

${ }^{18}$ Ibidem, p. 29.

${ }^{19}$ Magdalena Bar, Jerzy Jendrośka, Ocena oddziatywania przedsięwzięć na środowisko a ocena oddziatywania na obszar Natura 2000, [in:] Bartosz Rakoczy, Marcin Pchałek (ed.), Wybrane problemy prawa ochrony środowiska, Warsaw 2010, p. 24 
always obliged, in case of such kind of undertakings, to make individual selection, based on the statutory defined criteria. If it finds no need to carry out the assessment by issuing resolution, the assessment will not be carried out. During the individual selection authority will obtain the regional director for environmental protection' opinion, which is not bound. Contrary to recommendation contained in the opinion, the general public administration authority can withdraw from the assessment carrying out. Regional director for environmental protection will not have also the possibility of challenging such withdrawal (the resolution is not a subject of appeal, the agreeing procedure is available only when the assessment is carried out $)^{20}$.

\section{OTHER FORMS OF NATURE CONSERVATION}

Even if the Polish legislator has entrusted the administration of some forms of nature conservation to authorities having no specialized knowledge, such as provincial assembly (landscape parks or protected landscape areas) or commune council (object-oriented forms of nature conservation) requires always agreement achieving with the proper regional director for environmental protection. It is considered that the agreement achieving means the need for consent expressing (it is binding), both regarding the issue of the act, as well as its content. It was unequivocally supported by the Constitutional Court, according to whose opinion expressed in judgement of 13 May 2009, a draft of the provincial assembly resolution will require an agreement for all the elements which will be included in the resolution (also the set of bans) ${ }^{21}$. Although the content of Article 16 item 4 and Article 23 item 3 of Act on Nature Conservation does not express clearly (which should be evaluated negatively) the need of agreeing the drafts of other resolutions by the provincial assemblies with regional director for environmental protection (i.e. set of bans changing), such obligation should be derived from assigned tasks and competences of the

\footnotetext{
${ }^{20}$ Ibidem, p. 25, 26.

${ }^{21}$ Ref. No. of files: Kp. 2/09, LEX No. 493281.
} 
regional director for environmental protection ${ }^{22}$. This is essential also for this reason that the provincial assembly is non-specialized public administration authority with regard to nature conservation and it does not have required professional knowledge needed for proper (on its own) tackling those issues. On the other hand, agreement instrument implementation between administration authorities results in a situation in which this is the regional director for environmental protection who in practice creates the content of the resolution, whereas the provincial assembly (being unable to verify the resolution correctness and completeness) being a body formally issuing the resolution, is responsible for the arrangements made by the regional director for environmental protection (improprieties, incompleteness). In the area of the landscape park and protected landscape areas, bans selected from the statutory catalogue of bans defined in Article 17 item 1 of Act on Nature Conservation (with regard to landscape park) or in Article 24 item 1 of Act on Nature Conservation (with regard to protected landscape areas) may be introduced, by virtue of creating act, by authority appointing particular form of nature conservation, which should consider demands (needs) of particular subject. In principle, such a legal regime is designed to allow for better adaptation of protection type to the needs of specific subject. As indicated by the researchers, a set of bans that may be applicable in landscape parks (as well as in areas of protected landscape) has a double role. On the one hand, it is a pattern of bans that may be applied in landscape parks, on the other hand it constitutes an "maximum limit" what can be prohibited ${ }^{23}$. One should, however, consider the need for a statutory designation of "minimum limit" of bans binding on protected areas. Such a large freedom granted to authority responsible for creation of forms of nature conservation, which in addition is a authority of general public administration (while simultaneous lack of the specialized body responsibility for the resolution content), with regard to imple-

22 Por. Dorota Lebowa, Podstawy prawne funkcjonowania parków krajobrazowych $w$ Polsce, [in:] Marek Górski, Jolanta Bucińska, Monika Niedziółka, Roman Stec, Dorota Strus (ed), Administracja publiczna - cztowiek a ochron środowiska. Zagadnienia spoteczno-prawne, Warsaw 2011, p. 185-186.

${ }^{23}$ Wojciech Radecki, Uzgadnianie rozporzadzeń w parkach krajobrazowych i obszarach chronionego krajobrazu, Aura 2005, No. 5, p. 36. 
mentation of bans on that areas allows even (which unfortunately is the case with several landscape parks in Poland) for entire resignation from any bans appointing. This, in turn, seems to contradict the fundamental reason for forms of nature conservation creating (for protection covering in order to be able to prohibit the behaviours threatening the protected subject).

\section{CONCLUSIONS}

Specialized authorities in the field of environmental protection have existed since the beginning of the creation of the system of organization of environmental services and the amount of them has been steadily widening. This has been particularly evident in case of nature conservation law which is a part of environmental law. The fact of existence of authorities having specialized knowledge is particularly important in the context of new environmental tasks resulting from the implementation of European Union legal norms often using professional knowledge (e.g. with regard to Natura 2000 sites). Polish legislator has rightly made an assumption, that it is essential to entrust mainly the specialized nature conservation authorises (no general administration bodies which apart from tasks regarding nature conservation, perform many other tasks) the following issues: appointing and elimination of areas characterized with stringent or mitigated protective rigours; determination of the applicable legal regime; the assessment of criteria justifying derogations introducing from the bans; preparation of conservation plans that are an essential management tool and performing other activities which require extensive professional knowledge. Even if the Polish legislator has entrusted the administration of some forms of nature conservation to authorities having no specialized knowledge, such as provincial assembly (landscape parks or protected landscape areas) or commune council (object-oriented forms of nature conservation) requires always agreement achieving with the proper regional director for environmental protection. Carrying out tasks regarding administration of forms of conservation must be based on a good knowledge of the health of flora and fauna at the local scale, it must be also taken into account the ecolog- 
ical role of the particular area, subject or species on a scale of transnational. Such approach adopting has direct influence on effectiveness of those regulations in practice and taking of protective activities within nature conservation. It is important especially in the context of the fact that in Poland it is unfortunately sill quite often that crucial decisions regarding environmental protection matters (required specialized knowledge), other than nature conservation matters, are issued by village administrator, mayor, president of a town (while existing of specialized environmental protection authorities). However, there are few issues which required Polish legislator' intervention to bolster effectiveness of the form of nature conservation administration by public authorities.

\section{REFERENCES:}

Bar, Magdalena, Jerzy Jendrośka. 2010. Ocena oddziatywania przedsięwzięć na środowisko a ocena oddziatywania na obszar Natura 2000. In: Wybrane problemy prawa ochrony środowiska, ed. Bartosz Rakoczy, Marcin Pchałek, Warsaw;

Brodecki, Zdzisław (ed.). 2010. Ochrona przyrody przed Europejskim Trybunatem Sprawiedliwości. Komentarz, Marki;

Ciechanowicz-McLean, Janina, Prawo ochrony przyrody w systemie ochrony środowiska, Ochrona Środowiska. Prawo i Polityka [English: Environment Protection. Law and Policy] 2007, No. 1;

Górski, Marek. 2010. Wptyw nauk przyrodniczych i technicznych na treść, interpretacje $i$ stosowanie norm prawa administracyjnego (na przyktadzie przepisów z zakresu prawnej ochrony środowiska. In: Wspótzależność dyscyplin badawczych w sferze administracji publicznej, ed. Stanisław Wrzosek, Michał Domagała, Jan Izdebski, Tadeusz Stanisławski, Warszawa;

Lebowa, Dorota. 2011. Podstawy prawne funkcjonowania parków krajobrazowych w Polsce. In: Administracja publiczna - cztowiek a ochron środowiska. Zagadnienia spoteczno-prawne, ed. Marek Górski, Jolanta Bucińska, Monika Niedziółka, Roman Stec, Dorota Strus, Warsaw;

Lipiński, Aleksander. 2007. Prawne podstawy ochrony środowiska, Warszawa;

Radecki, Wojciech. 2008. Ustawa o ochronie przyrody. Komentarz, Warszawa;

Urban S., Negatywne oddziatywanie planów i przedsięwzięć na sieć Natura 2000 a nadrzędny interes publiczny. Analiza pojęcia "powody o charakterze zasadniczym wynikające z nadrzędnego interesu publicznego" [in:] J. Jendrośka, M. Bar, 
Wspólnotowe prawo ochrony środowiska i jego implementacja w Polsce trzy lata po akcesji, Wrocław 2008;

Urban, S., Opinie Komisji Europejskiej w sprawie planów i przedsięwzięć negatywnie oddziatujacych na obszary Natura 2000; Problemy ocen środowiskowych [English: Problems with Environmantal Assessments] 2006, No. 1;

Woźniak, Marta. 2008. Rola samorzadu terytorialnego $w$ implementacji prawa wspólnotowego na przyktadzie prawa ochrony środowiska. In: Wspólnotowe prawo ochrony środowiska i jego implementacja $w$ Polsce trzy lata po akcesji, ed. Jerzy Jendrośka, Magdalena Bar, Warszawa; 